RFP-1821

March 24, 1972

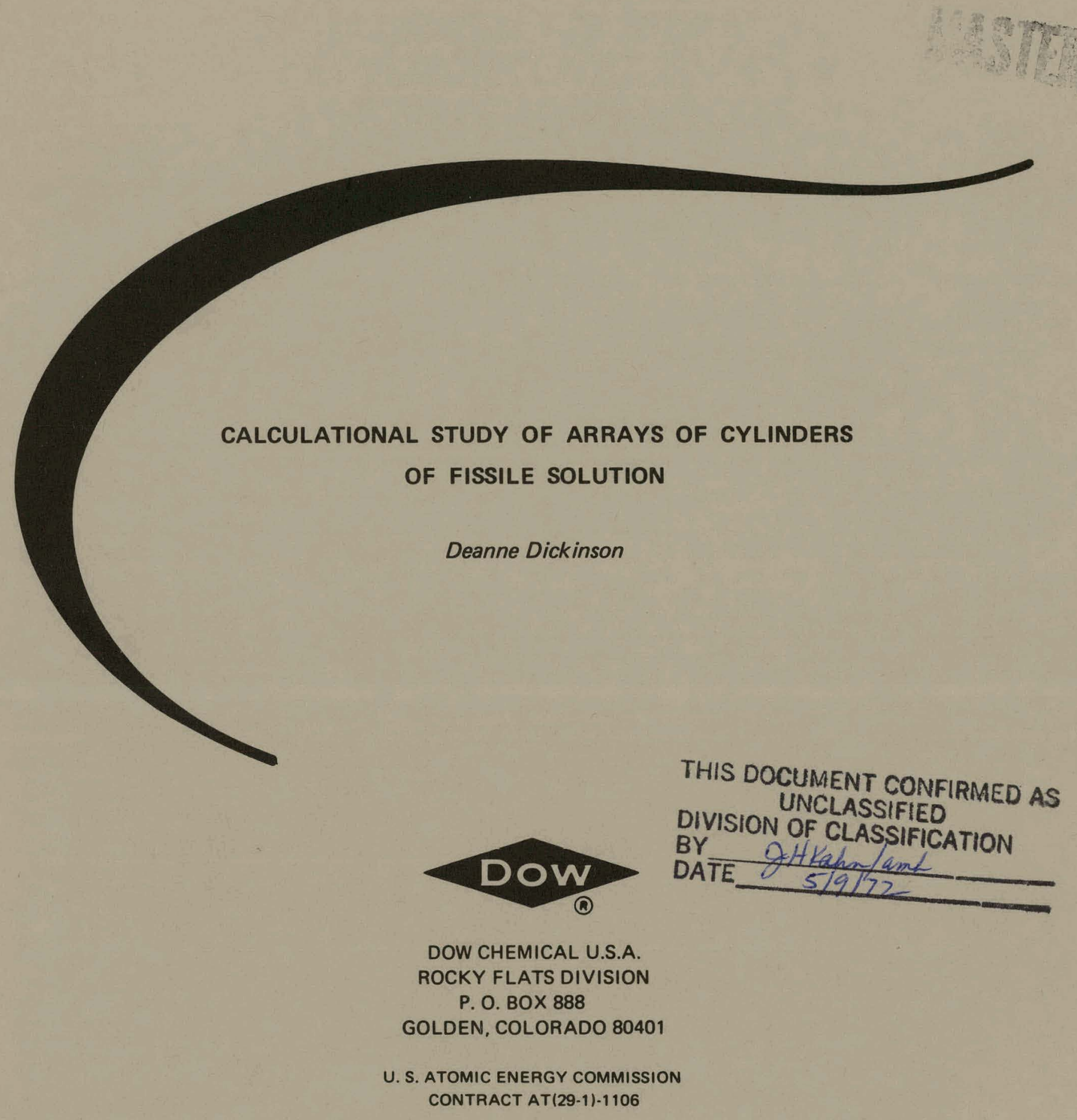




\section{DISCLAIMER}

This report was prepared as an account of work sponsored by an agency of the United States Government. Neither the United States Government nor any agency Thereof, nor any of their employees, makes any warranty, express or implied, or assumes any legal liability or responsibility for the accuracy, completeness, or usefulness of any information, apparatus, product, or process disclosed, or represents that its use would not infringe privately owned rights. Reference herein to any specific commercial product, process, or service by trade name, trademark, manufacturer, or otherwise does not necessarily constitute or imply its endorsement, recommendation, or favoring by the United States Government or any agency thereof. The views and opinions of authors expressed herein do not necessarily state or reflect those of the United States Government or any agency thereof. 


\section{DISCLAIMER}

Portions of this document may be illegible in electronic image products. Images are produced from the best available original document. 


\section{LEGAL NOTICE}

This report was prepared as an account of work sponsored by the United States Government. Neither the United States nor the United States Atomic Energy Commission, nor any of their employees, nor any of their contractors, subcontractors, or their employees, makes any warranty, expressed or implied, or assumes any legal liability or responsibility for the accuracy, completeness or usefulness of any information, apparatus, product or process disclosed, or represents that its use would not infringe privately owned rights.

Printed in the United States of America Available from the National Technical Information Service

U. S. Department of Commerce Springfield, Virginia 22151

Price: Printed Copy $\$ 3.00$ : Microfiche $\$ 0.65$ 


\title{
CALCULATIONAL STUDY OF ARRAYS OF CYLINDERS OF FISSILE SOLUTION
}

\author{
Deanne Dickinson
}

Research and Ecology

NUCLEAR SAFETY GROUP

\begin{abstract}
This rennrt was nrepared as an arcount of work sponsored by the United States Government. Neither the United States nor the United States Atomic Energy Commission, nor any of their employees, nor any of their contractors, subcontractors; or their employees, makes any warranty, express or implied, or assumes any legal liability or responsibility. for the accuracy, completeness or usefulness of any information, apparatus, product or process disclosed, or represents that its use would not infringe privately owned rights.
\end{abstract}

DOW CHEMICAL U.S.A.

ROCKY FLATS DIVISION

P. O. BOX 888

GOLDEN, COLORADO 80401

\author{
Prepared under Contract AT(29-1)-1106 \\ for the \\ Albuquerque Operations Office
}

U.'S. Atomic Energy Commlssiun 


\section{CONTENTS}

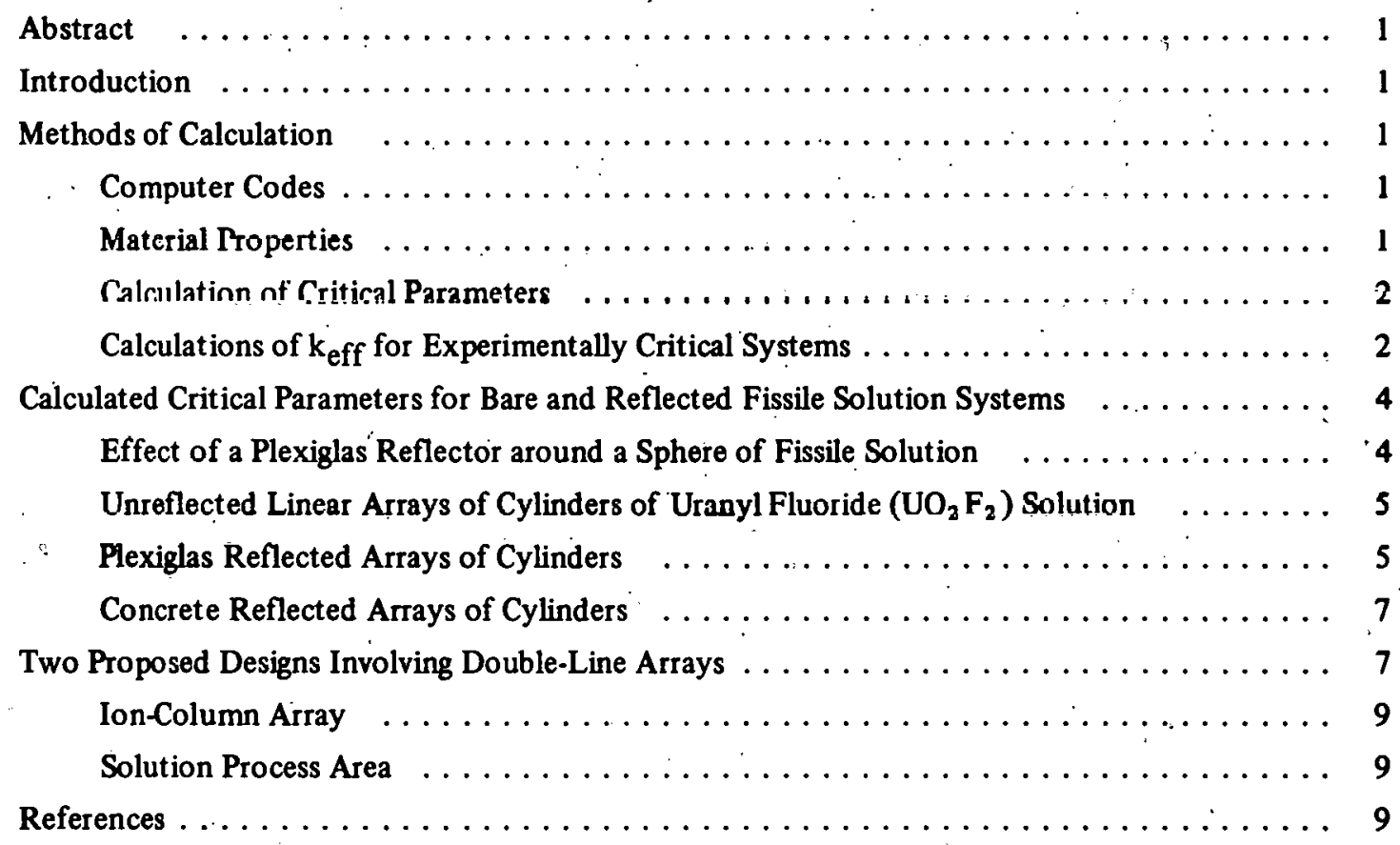




\title{
CALCULATIONAL STUDY OF ARRAYS OF CYLINDERS OF FISSILE SOLUTION
}

\author{
Deanne Dickinson
}

\begin{abstract}
Values of $\mathrm{k}_{\mathrm{eff}}$ for experimentally critical systems of enriched uranium or plutonium solution are calculated using the DTF-II, KENO, and KENO II computer codes. Both KENO and KENO II underestimate $k_{\text {eff (effective }}$ neutron multiplication factor) for minimally reflected uranium-solution systems, indicating that some correction is needed if these codes are to be used conservatively in nuclear safety calculations. Calculated critical parameters are presented for line arrays of long cylinders of fissile solution reflected by Plexiglas or concrete. The reflector is a cuboidal shell, simulating a room, and the distance from the sides of the shell to the array is varied. Two examples of double-line arrays are presented.
\end{abstract}

\section{INTRODUCTION}

The storage and processing of fissile solution are often done in annular cylinders or in long cylinders of small diameter to satisfy nuclear safety requirements. In this report, only the case of long (effectively infinite length) cylinders will be considered. For a safe long cylinder, a necessary requirement would be to have a diameter smaller than the critical diameter for an infinite cylinder containing the same fissile solution and having the same external reflection. Onedimensional transport theory can be used to estimate the critical infinite cylinder diameter, and some data are available from Paxton et al. (7). ${ }^{1}$

In actual situations, one usually has a one- or twodimensional array of cylinders with a variety of reflectors at different distances from the array. These reflectors include the walls, floor, and ceiling of the room containing the cylinders and, in some cases, glove boxes and biological shielding.

Some of the parameters which affect the reactivity of a fissile-solution system are the solution composition, the container shape and material, the number of units, the arrangement of units (configuration and spacing), and the presence of moderators or reflectors. In this report, the number of parameters has been reduced by considering linear arrays of long cylinders. Both the cylinder length and the array length are effectively infinite; i.e., increasing the cylinder height or extending the array by adding more units would have a negligible effect on system reactivity. The variables studied include cylinder diameter and spacing, and the effect of the position of an external reflector.

\footnotetext{
INumerals in parentheses relate to references given at end of text.
}

The first section of the report is concerned with establishing the validity of the computer codes and cross-section data used by performing calculations on experimentally determined critical systems. The next section presents calculated critical parameters for line arrays, both bare and reflected, for uranium and plutonium solutions. The information has application in preliminary design calculations involving line arrays. Finally, two examples of double-line arrays considered in the planning of a new building are discussed.

\section{METHODS OF CALCULATION}

\section{Computer Codes:}

The Monte Carlo codes KENO (11) and KENO II (12) were used for most of the calculations, since a threedimensional geometry description was necessary. KENO II is an improved version of the KENO code having a similar neutronics calculation and a more versatile geometry routine. Some calculations on spherical systems were done with the one-dimensional transport code, DTF II (3). All three codes use the Hansen-Roach sixteen group cross sections (5).

Calculated values of $\mathrm{k}_{\text {eff }}$, the effective neutron multiplication factor, are given with error bars of one standard error, denoted as sigma $(\sigma)$; i.e., the 68-percent confidence interval. In recent versions of KENO and KENO II, the Shapirn-Wilk test for normality (9) is used to determine if the $\mathrm{k}_{\mathrm{eff}}$ values are approximately normally distributed, and hence if the sample standard error is a reliable estimate of the error in the average $k_{\text {eff }}$. Calculations which fail the Shapiro-Wilk test are indicated.

\section{Material Properties:}

All references to uranyl fluoride $\left(\mathrm{UO}_{2} \mathrm{~F}_{2}\right)$ solution are to the uranium solution described in Table $\mathrm{I}$. The solution properties are taken from Fox et al. (4), where it is stated that this concentration gives the minimum critical volume for reflected systems. Similarly, all references to $200 \mathrm{grams}$ per liter $(\mathrm{g} / \mathrm{l})$ plutonium nitrate $\left[\mathrm{Pu}\left(\mathrm{NO}_{3}\right)_{4}\right]$ solution are to the plutonium solution described also in Table $\mathrm{I}$. This is an artificial solution, since it contains no excess nitric acid, and hence is more reactive than real solutions, which always contain some excess nitric acid. The $200-\mathrm{g} / 1$ concentration is believed to be close to the minimum critical volume concentration for aqueous solutions of plutonium nitrate containing 5 percent of plutonium-240 $\left({ }^{240} \mathrm{Pu}\right)$ and no excess actd. 
TABLE I. Fissile Solution Compositions.

\begin{tabular}{|c|c|c|}
\hline & $\begin{array}{l}\text { Uranyl Fluoride } \\
\left(\mathrm{UO}_{2} \mathrm{~F}_{2}\right) \\
\text { Solution }\end{array}$ & $\begin{array}{c}\text { Plutonium Nitrate } \\
{\left[\mathrm{Pu}\left(\mathrm{NO}_{3}\right)_{4}\right]} \\
\text { Solution }\end{array}$ \\
\hline Concentration & $\begin{array}{l}576.82 \text { grams of } \\
\text { uranium per liter }\end{array}$ & $\begin{array}{l}200 \text { grams of } \\
\text { plutonium per } \\
\text { liter }\end{array}$ \\
\hline Enrichment & $\begin{array}{l}93.2 \text { weight percent } \\
\text { of uranium-235 } \\
\left({ }^{20} \mathrm{U}\right)\end{array}$ & $\begin{array}{l}95 \text { weight percent } \\
\text { of plutonium-239 } \\
(198 \mathrm{Pi})\end{array}$ \\
\hline Specific Gravity & 1.661 & 1.316 \\
\hline${ }^{\mathrm{a}} \mathrm{H} / \mathrm{X}$ & $\mathrm{H} / /^{235} \mathrm{U}=44.3$ & $\mathrm{H} / /^{239} \mathrm{Pu}=126$. \\
\hline
\end{tabular}

Calculation of Critical Parameters:

Critical parameters are calculated by linear interpolation, using points close enough to critical that any departure from linearity is negligible compared to statistical errors. If only two data points were available, the critical value of the parameter was calculated by linear interpolation between them, and errors were estimated by the formula ${ }^{2}$ for propagation of errors (1). If more than two data points were found, a linear least squares fit was made, and the resulting equation was solved for the critical value of the parameter. The error is estimated by the method described in Kenney et al. (6, Section 8.10). It is important to note that, because the random variable involved is not normally distributed, one cannot assume any relation between the error bars for the 68-percent confidence interval and the error bars for any other confidence interval.

Calculations of $\mathbf{k}_{\text {eff }}$ for Experimentally Critical Systems: All three computer codes used in this report were checked against experimentally determined critical systems for both uranium and plutonium solutions, bare and reflected.

Several KENO and KENO II calculations were done on arrays of cylinders of $\mathrm{UO}_{2} \mathrm{~F}_{2}$ solution (as described in Table I) using the critical data of Fox et al. (4). The calculational results shown in Table II imply that both codes give values of $k_{\text {eff }}$ about 1 to 2-percent low for minimally reflected systems. Further calculations showed

\footnotetext{
${ }^{2}$ The method was pointed out in discussion with Robert E. Rothe of Nuclear Safet $y$, who also derived the specific formula used.
}

that this is equivalent to overestimating the critical diameter by 3 to 4 percent. Calculations for watermoderated and reflected arrays were in good agreement with experiment, with the exception of one case for which $\mathrm{k}_{\text {eff }}$ was too high by about 3 percent.

Since the $200-\mathrm{g} / \mathrm{l}$ plutonium solution is artificial, no comparisons with experiment are possible. However, transport and diffusion-theory calculations have been done (B) which show that Ilanisesi=Ruach cuuss sectivis give conservative results for spherical $\mathrm{Pu}\left(\mathrm{NO}_{3}\right)_{4}$ solution systems, both bare and reflected, for plutonium concentrations ranging from 24.4 to $268 \mathrm{~g} / \mathrm{l}$ and ${ }^{240} \mathrm{Pu}$ content ranging from 0.54 to 4.6 percent.

Several cases from Richey (8) and Bouly et al. (2) were checked usirig KENO and KENO II. The resuits are presentcd in Tables III and IV. The KENO code gives $\mathbf{k}_{\text {eff }}>1$ for all the plutonium solutions, both bare and reflected. KENO II gives satisfactory results for waterieflected plutuniun sulutlun systentis, but luw values of $k_{\text {eff }}$ for two of the six bare systems. The reason for the low values of $k_{\text {eff }}$ for the bare solution spheres (Table III) is not known, but it may be the omission of the room and surrounding apparatus.

Most of the calculations in this report are for arrays reflected by a cuboidal shell of Plexiglas or concrete. Data on uranium-solution cylinder arrays interacting with a solution slab and reflected by Plexiglas are given by Tuck and Clark (10), and Monte Carlo calculations for these systems are presented in Table V. The results are in excellent agreement with the experimental data.

The results of all calculations on experimental data are summarized in Table VI. In two cases, the average $k_{\text {eff }}$ is less than nne (hare uranium solution with KF.NO or KENO II), indicating that somc correction is nceded if. calculations are to be used conservatively for nuclear safety considerations. The magnitude of these corrections is not known and would probably have to be determined separately for each specific geometry. Also, no experimental data are available for units and arrays reflected by a cuboidal shell of concrete, and it is exactly this case which occurs in practice for solution systems contained in a concrete room. A comparison of the energy spectra of neutrons causing fissions for the various cases shows that the concreteshell reflector results in a spectrum intermediate between that of the bare case and the Plexiglas-shell reflected system. However, it is impossible to determine from the available data whether calculations on solution arrays in a concrete shell reflector are conservative. 
RFP-1821

TABLE II. Results of Monte Carlo Calculations for Experimentally Critical Arrays of Cylinders Containing Uranyl Fluoride Solution.

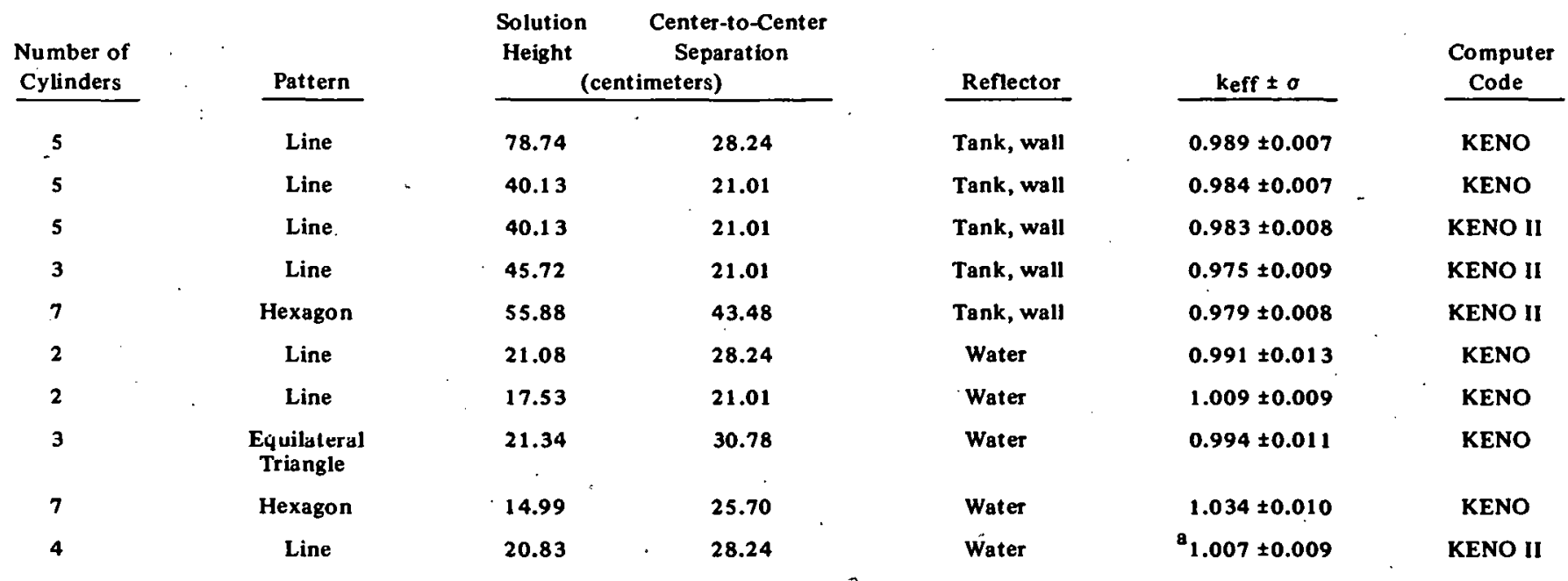

NOTE: The experimental data were given by Fox et al, see Reference 4. The fissile solution is uranyl fluoride $\left(\mathrm{UO}_{2} \mathrm{~F}_{2}\right)$ as described in Table 1 . The cylinders are aluminum with an inner diameter of 8 inches and a wall thickness of 0.06 inches. The cylinders are in a tank 9.5 feet in dia meter, 10 feet high, lateral wall of 0.375 -inch mild steel clad with 0.063 -inch stainless steel, bottom 1-inch mild steel clad with 0.063 -inch stainless steel. The bottoms of the solution cylinders are 12 inches above the tank bottom. For the reflected arrays, the tank is filled with water to the level of the solution in the cylinders. For the arrays not reflected.by water, one concrete wall was placed . 6 feet from the tank.

${ }^{a}$ This case fails the Shapiro-Wilk test at the 1-percent significance level (see Reference 9).

TABLE III. Results of Transport and Monte Carlo Calculations for Critical Spheres of Plutonium Nitrate Solution.

\begin{tabular}{|c|c|c|c|c|c|c|}
\hline $\begin{array}{c}\text { Sphere } \\
\text { Diameter } \\
\text { (centimeters) }\end{array}$ & $\begin{array}{c}\text { 20-Centimeter } \\
\text { Water } \\
\text { Reflected }\end{array}$ & $\begin{array}{c}\text { Plutonium } \\
\text { Concentration } \\
\text { (grams per liter) }\end{array}$ & $\begin{array}{c}\begin{array}{c}\text { Weight Percent } \\
\text { of } \\
\text { Plutonium-240 }\end{array} \\
\end{array}$ & $\mathrm{H}^{+}$Normality & $k_{\text {eff }} \pm \sigma$ & Computer Code \\
\hline 29.21 & Yes & 132. & 4.6 & $\grave{2.25}$ & $1.027 \pm 0.008$ & KENO \\
\hline 29.21 & Yes & 132. & 4.6 & 2.25 & $0.991 \pm 0.009$ & KENO II \\
\hline 29.21 & Yes & 268.7 & 4.6 & 1.08 & 1.046 & DTF II \\
\hline 29.21 & Yes & 268.7 & 4.6 & 1.08 & $1.052 \pm 0.008$ & KENO \\
\hline 35.56 & Yes & 27.91 & 0.54 & 1.72 & $1.000 \pm 0.010$ & KENO II \\
\hline 38.61 & No & 39. & 4.6 & 0.363 & 1.015 & DTF II \\
\hline 38.6 & No & 39. & 4.6 & 0.363 & $1.029 \pm 0.008$ & KENO \\
\hline 38.6 & No & 39. & 4.6 & 0.363 & $0.987 \pm 0.008$ & KENO II \\
\hline
\end{tabular}

NOTE: Critical parameters were obtained from Tables I and III of Reference 8, C. R. Richey.

\footnotetext{
${ }^{\mathrm{a}}$ Test significant at 10 percent level, see Reférence 9 , Shapiro and Wilk.
} 
RFP-1821

TABLE IV. Results of Monte Carlo Calculations for Experimentally Critical Arrays of Plutonium Nitrate Solution in Air.

\begin{tabular}{|c|c|c|c|c|c|}
\hline \multirow[b]{2}{*}{ Number of Cylinders } & \multirow[b]{2}{*}{ Pattern } & Sulution Height & $\begin{array}{l}\text { enter-to-Center } \\
\text { Separation }\end{array}$ & \multirow[b]{2}{*}{$k_{\text {eff }} \pm \sigma$} & \multirow{2}{*}{$\begin{array}{c}\text { Compute } \\
\text { Code }\end{array}$} \\
\hline & & (cent & & & \\
\hline 1 & - & 42.53 & - & $1.018 \pm 0.009$ & KENO \\
\hline 2 & Line & 39.72 & 60. & $1.027 \pm 0.008$ & KENO \\
\hline 3 & $\begin{array}{c}\text { Equilateral } \\
\text { Triangle }\end{array}$ & 37.30 & 60. & $1.014 \pm 0.009$ & KENO $11^{-}$ \\
\hline 3 & $\begin{array}{l}\text { Equilateral } \\
\text { Triarigle }\end{array}$ & 39.90 & 90. & $1.001 \pm 0.008$ & KENO II \\
\hline $\mathbf{3}$ & $\begin{array}{c}\text { Right } \\
\text { Triangle }\end{array}$ & 26.58 & ${ }^{\mathrm{a}} 30$. & $1.005 \pm 0.009$ & KENO II \\
\hline 4 & Square & 22.96 & 30. ${ }^{-}$ & $1.002 \pm 0.010$ & KENO II \\
\hline
\end{tabular}

NOTE: The critical experiments were reported in Reference 2. The fissile solution is 152.5 grams per liter plutonium nitrate, 2.24 normal, 95.47 weight percent plutonium-2 39. The cylinders are 29.4 -centimeters (cm) inslde diameler wilh 0.3 -cill tlick stainless steel walls. The hood and room were inciuded in the geometry description, but several calculations wil houl them showed that theif éf tect on $k_{\text {eff }}$ is s̄mâll ( $\approx 2$ pèt cent maximum).

${ }^{\mathrm{a}}$ The separation refers to distances along the legs of the right triangle only.

TABLE V. Montc Carlo Calculations for Uranyl Nitrate $\left[\mathrm{UO}_{2}\left(\mathrm{NO}_{3}\right)_{2}\right]$ Solution Cylinder Arrays in a Solution Slab Reflected by a Cuboidal Shell of Plexiglas.

\begin{tabular}{|c|c|c|c|c|c|c|}
\hline $\begin{array}{l}\text { Number of } \\
\text { Cylinders } \\
\text { il Array }\end{array}$ & $\begin{array}{c}\text { Solution Slab } \\
\text { Thickness } \\
\text { (cent }\end{array}$ & $\begin{array}{l}{ }^{\text {a }} \text { Height of } \\
\text { Solution in } \\
\text { Cylinders } \\
\text { ) }\end{array}$ & $\begin{array}{c}\begin{array}{c}\text { Uranium } \\
\text { Concentration } \\
\text { (grams per liter) }\end{array} \\
\end{array}$ & $\begin{array}{l}\text { Top and Side } \\
\text { Reflector } \\
\text { Thickness } \\
\text { (centimeters) } \\
\end{array}$ & $k_{\mathrm{eff}} \pm n$ & Computer Code \\
\hline 9 & 9.5 & 20. & 505. & 10.2 & $1.007 \pm 0.010$ & KENO \\
\hline 16 & 0. & 92. & 505. & 10.2 & $1.015 \pm 0.010$ & KENO II \\
\hline 16 & 3.8 & 61. & 505. & 10.2 & $0,999 \pm 0,009$ & KENO \\
\hline 16 & 0. & 96. & 510. & 7.6 & $0.996 \pm 0.011$ & KENO II \\
\hline 10 & 0. & 105: & 610. & 6.1 & $1.005+n .011$ & KFNO II \\
\hline
\end{tabular}

NOTE: Experimental critical data are from Table VI of Reference 10, Tuck and Clark. The cyllindè oiameter is 1 is.b centimeters (cm). The cylinder walls were of $0.28-\mathrm{cm}$ stainless steel. The botto $\mathrm{m}$ reflector thickness is $10.2-\mathrm{cm}$ in all cases.

${ }^{\mathrm{a}}$ Measured from top of solution slab.

TABLE VI. Average $k_{\text {eff }}$. for each Type of System Represented in Tables II, III, IV, and V.

\begin{tabular}{|c|c|c|c|}
\hline \multicolumn{2}{|c|}{ System } & \multirow{2}{*}{$\frac{\text { KENO }}{0.987 \pm 0.004}$} & \multirow{2}{*}{$\frac{\text { KENO II }}{0.979 \pm 0.004}$} \\
\hline \multirow{3}{*}{$\begin{array}{l}\text { Uranium } \\
\text { Solution }\end{array}$} & Rạre & & \\
\hline & $\begin{array}{l}\text { Plexiglas Shell } \\
\text { Reflected }\end{array}$ & $1.003 \pm 0.006$ & $1.005 \pm 0.010$ \\
\hline & Reflected & $1.007 \pm 0.020$ & $a_{1.007}$ \\
\hline \multirow{2}{*}{$\begin{array}{l}\text { Plutonium } \\
\text { Solution }\end{array}$} & Bare & $1.019 \pm 0.013$ & $0.998 \pm 0.013$ \\
\hline & Reflected & $1.040 \pm 0.018$ & $1.003 \pm 0.014$ \\
\hline
\end{tabular}

\section{CA LCULATED CRITICAL PARAMETERS FOR BARE AND REFLECTED FISSILE SOLUTION SYSTEMS}

The purpose of this section is to provide calculated values of uitical parameters for lincar arrays of cylinders of fiseile solution. While no design problem is expected to fit exactly the situations considered, the data provided can serve as a starting point for calculations.

Effect of a Plexiglas Keflector around à Sp̄here of Fissile Solution: Before studying the effect of reflector position on anarray, consider first the simpler problem of a single sphere of fissile solution reflected by a 15.24 centimeter (cm) thick shell of Plexiglas and vary the inner radius of 
TABLE VII. Calculations for a Sphere of Uranium or Plutonium Solution Reflected by a Shell of Plexiglas.

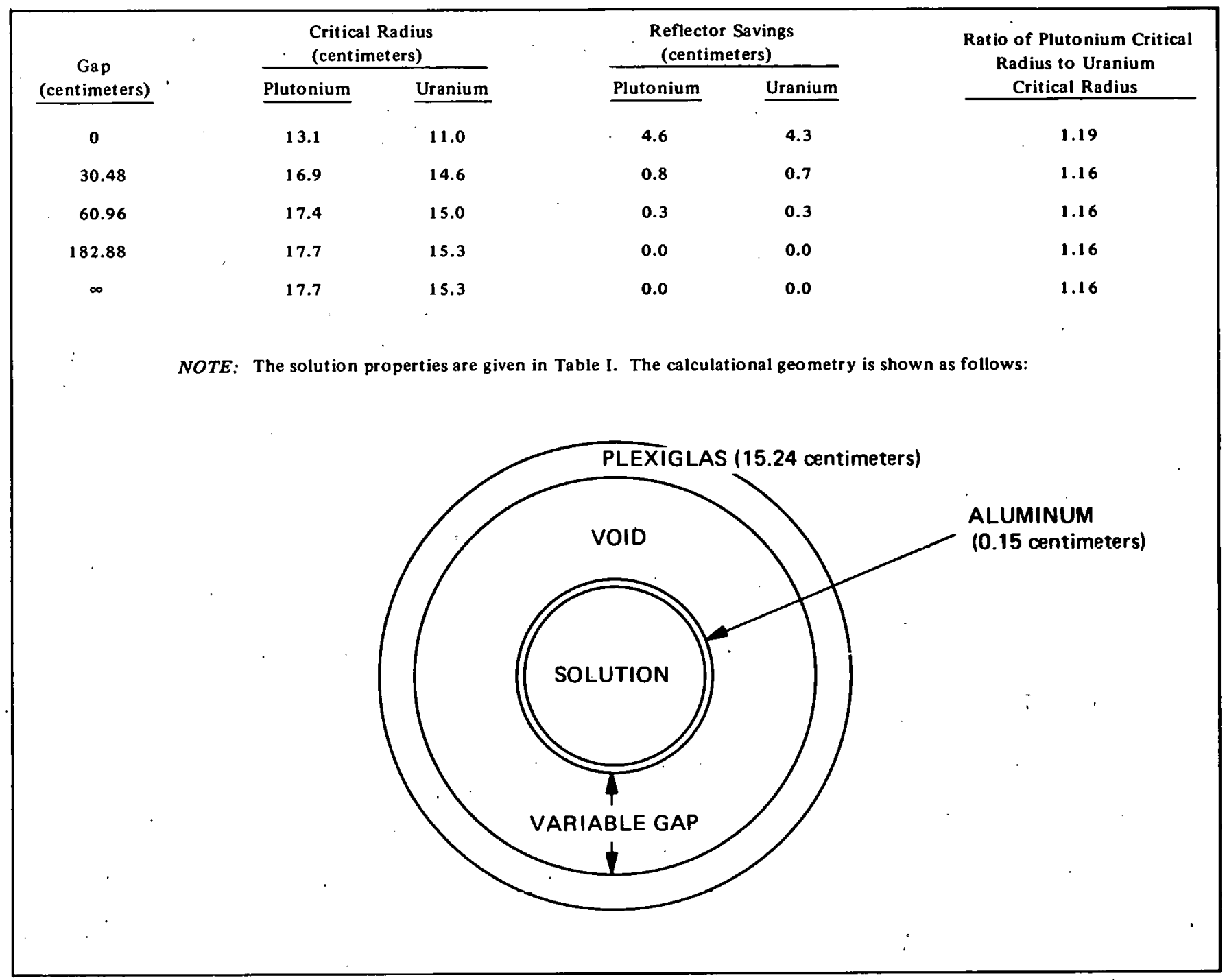

the shell. Later, the same problem will be treated for the case of a Plexiglas-shell reflector around a line array of solution cylinders.

The case of a single sphere may be calculated using the DTF-Il code (3). The results are shown in Table VII and refer also to Figure 1. For the reflector at a distance of $30 \mathrm{~cm}$ or more, the critical radius of the plutoniumsolution sphere is larger than the critical radius of the uranium-solution sphere by a constant 16 percent. No such

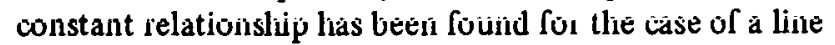
array of cylinders.

\section{Unreflected Linear Arrays of Cylinders of Uranyl Fluoride} $\left(\mathrm{UO}_{2} \mathrm{~F}_{2}\right)$ Solution: A series of KENO calculations was done to find the variation in critical separation as a function of the number of cylinders in a bare, linear array of $20.32-\mathrm{cm}$ diameter, $250-\mathrm{cm}$ long cylinders of uranyl fluoride $\left(\mathrm{UU}_{2} \mathrm{~F}_{2}\right)$. The cylinders have $0.15-\mathrm{cm}$ thick aluminum walls. These results are shown in Figure 2. The critical center-to-center separation is approximately constant (at $33.4 \mathrm{~cm}$ ) for any number of cylinders greater than 20. Later calculations, using the KENO II code (12), showed that an infinite line of $20.32-\mathrm{cm}$ diameter cylinders at 33.3-cm center-to-center spacing had a $\mathbf{k}_{\text {eff }}$ of $0.986 \pm 0.006$, compared to $k_{e f f}=0.981 \pm 0.006$ for a line of 30 cylinders. (The KENO code cannot handle infinite arrays.)

As a result of these calculations, further calculations on line arrays were done for a line of 30 cylinders. According to Figure 2 and the KENO II calculations, 30 cylinders are effectively infinite. 
RFP-1821

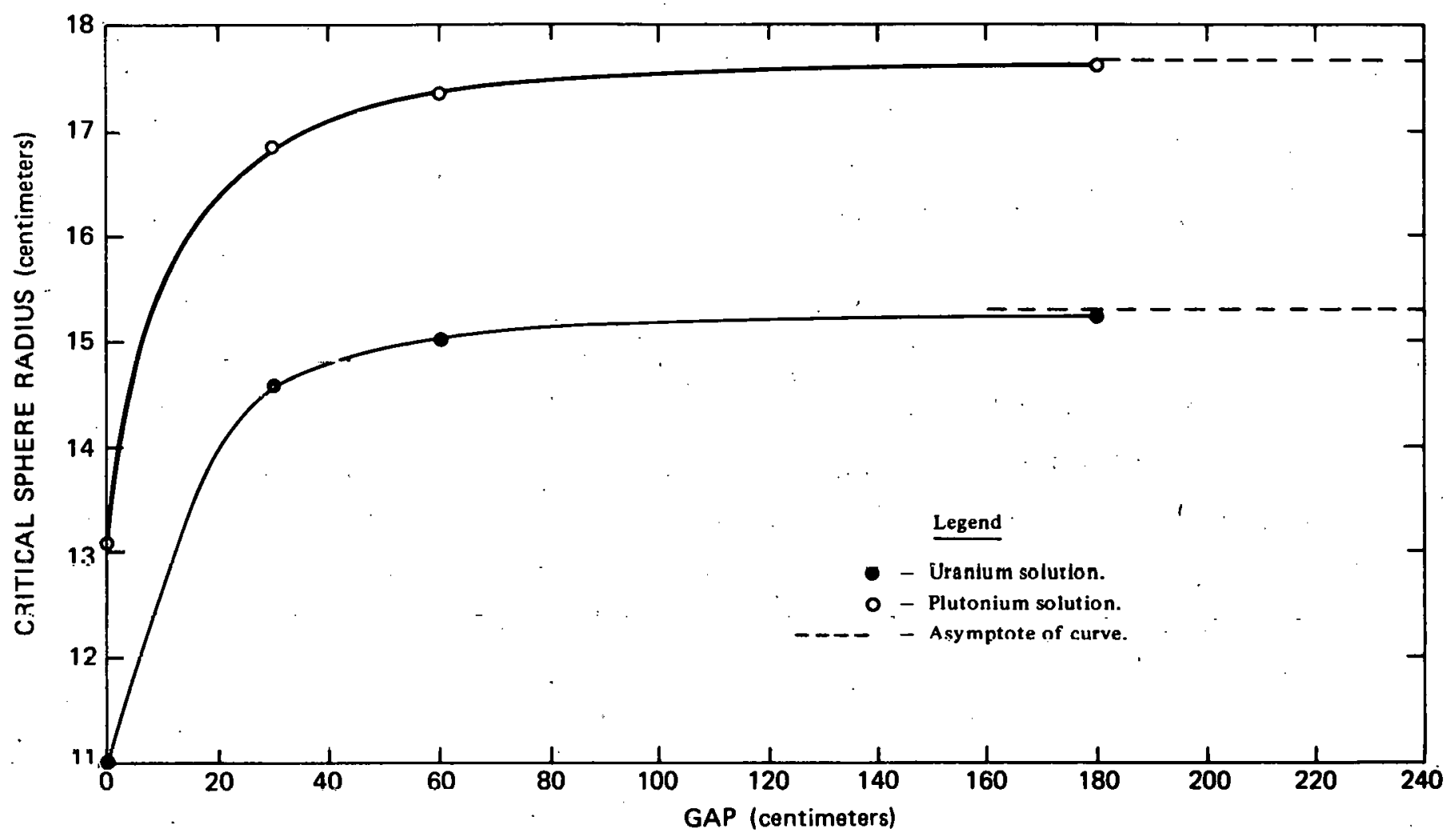

FIGURE 1. Critical Radius of a Uranium or Plutonium Solution Sphere as a Function of the Gap between the Sphere and a. Plexiglas Shell Reflector (15.24 centimeters thick).

FIGURE 2. Critical Center-to-Center Spacing for Unreflected Line Arrays of 20.32-Centimeter Diameter Cylinders of Uranyl Fluoride Solution versus Number of Cylinders in Array.

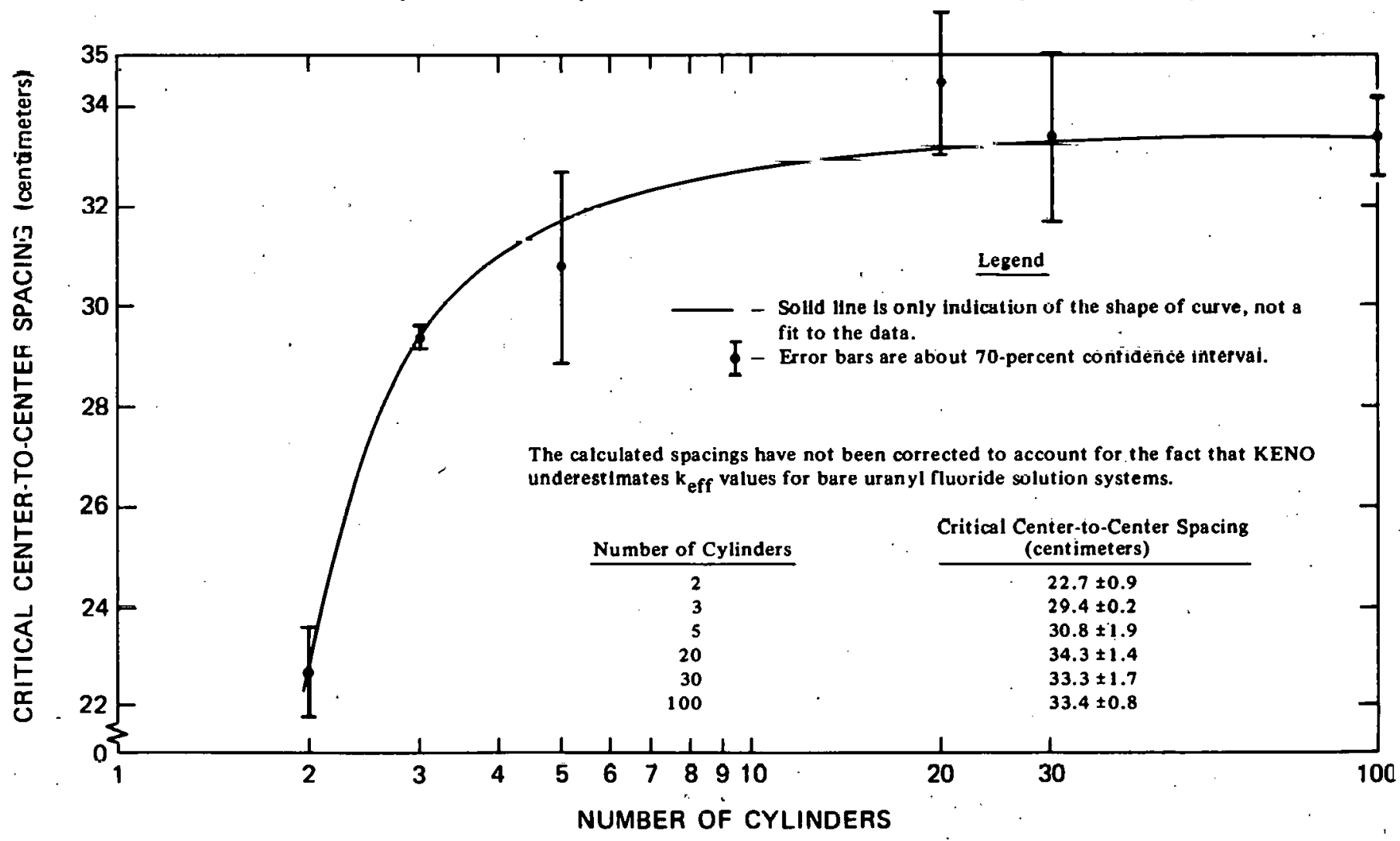




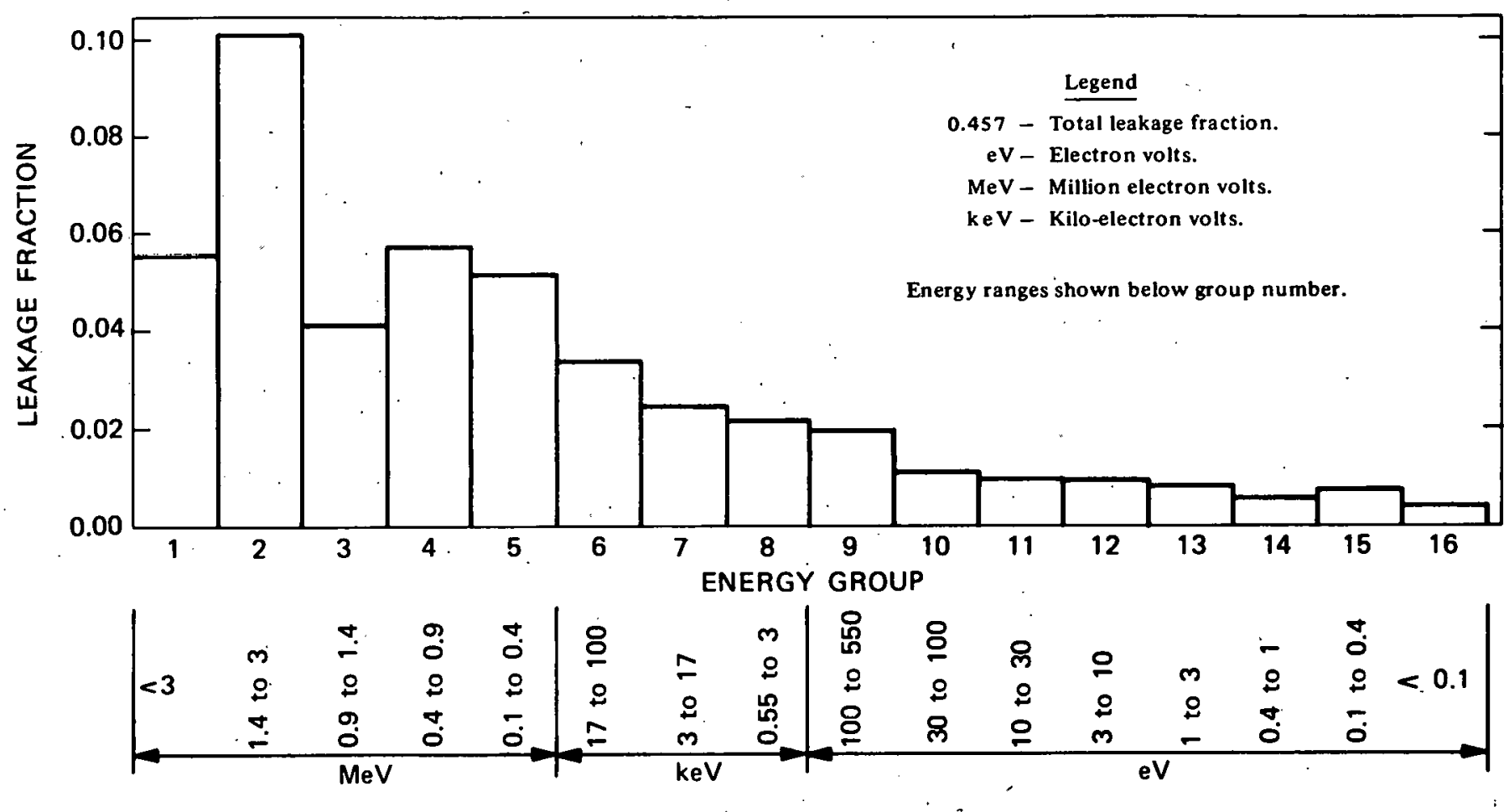

FIGURE 3. Leakage Spectrum for Critical Line Array of Thirty 20.32-Centimeter Diameter Cylinders of Uranyl Fluoride with a Center-to-Center Separation of 33.3 Centimeters.

The leakage spectrum by energy group for an unreflected line array of 30 cylinders is shown in Figure 3 . The ordinate of the graph is the neutron leakage fraction. The leakage fraction for an energy group is the probability that a neutron produced in the system will leave the system with an energy in the specified range.

Plexiglas Reflected Arrays of Cylinders: The effect of a 15.24-cm thick cuboidal shell Plexiglas reflector was studied for a line array of 30 cylinders, each cylinder having a height of $250 \mathrm{~cm}$. The center-to-center spacing of the cylinders was fixed, and the critical cylinder diameter was calculated using the KENO code for several reflector positions. The reflector was always kept in contact with the top and bottom of the cylinder array, and the distance of the lateral walls of the reflector from the lateral walls of the cylinders was varied. The results of these calculations are shown in Table VIII.

For the 33.02-cm center-to-center spacing, the plutonium critical diameter is always greater than the corresponding value for uranium but, unlike the case of the reflected single sphere, the increase varies from 6 to 18 percent. Some of this variation may be the result of statistical uncertainty in the calculated critical diameters.
Comparing the critical diameters for uranium solution at different center-to-center spacings, one finds that the critical diameters for the $60.96-\mathrm{cm}$ spacing are larger than those for the $33.02-\mathrm{cm}$ spacing by 6 to 14 percent. Again, some of this variation may be the result of statistical uncertainty.

Concrete Reflected Arrays of Cylinders: The KENO II code was used to calculate the critical spacing for an infinitely long line of cylinders of $\mathrm{UO}_{2} \mathrm{~F}_{2}$ solution of fixed diameter reflected by a shell of concrete $30.48 \mathrm{~cm}$ thick. The concrete was $30.48 \mathrm{~cm}$ from the lateral wall of the cylinder. The results are given in Table IX. These data can be used conservatively to estimate the critical spacing for a line array of cylinders in a concrete room, as.long as the nearest wall is at least $30.48 \mathrm{~cm}$ away.

\section{TWO PROPOSED DESIGNS INVOLVING DOUBLE-LINE ARRAYS}

Two examples of double-line arrays of long cylinders of interest for use at Rocky Flats are considered. Monte Carlo calculations are given for normal and abnormal conditions. 
TABLE VIII. Critical Diameters and Reflector Savings for a Line of Thirty Cylinders (250centimeter height) of Uranium or Plutonium Solution Reflected by 15.24 centimeters of Plexiglas.

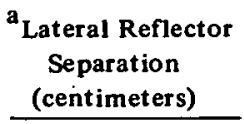

0

30.48

60.96

182.88

$\infty$

No Reflector

\begin{tabular}{|c|c|}
\hline \multicolumn{2}{|c|}{ Uranium Solution } \\
\hline $\begin{array}{c}\text { 33.02-centimeters } \\
\text { Center-to-Center } \\
\text { Spacing }\end{array}$ & $\begin{array}{c}\text { 60.96-centimeter } \\
\text { Center-to-Center } \\
\text { Spacing }\end{array}$ \\
\hline $13.31 \pm 0.49$ & $14.83 \pm 0.05$ \\
\hline $14.55 \pm 0.71$ & $16.36 \pm 0.08$ \\
\hline $16.05 \pm 1.14$ & $18.19 \pm 0.15$ \\
\hline $17.86 \pm 0.13$ & $18.77 \pm 0.05$ \\
\hline $18.80 \pm 0.08$ & $20.42 \pm 0.13$ \\
\hline $20.22 \pm 0.13$ & $21.46 \pm 0.08$ \\
\hline
\end{tabular}

timeters) Clutonium Solution

33.02-centimeters

Center-to-Center

Spacing

$14.46 \pm 0.40$

$16.31 \pm 0.61$

$1.7 .04 \pm 0.13$

$20.09 \pm 0.51$

$22.20 \pm 0.05$

$23.27 \pm 0.18$

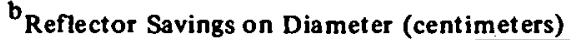

\begin{tabular}{|c|c|c|}
\hline \multicolumn{2}{|c|}{ Uranium Solution } & \multirow{2}{*}{$\begin{array}{c}\text { Plutonium Solution } \\
\text { 33.02-centimeters } \\
\text { Center-to-Center } \\
\text { Spacing } \\
\end{array}$} \\
\hline $\begin{array}{c}\text { 33.02-centimeters } \\
\text { Center-to-Center } \\
\text { Spacing } \\
\end{array}$ & $\begin{array}{c}\text { 60.96-centimeters } \\
\text { Center-to-Center } \\
\text { Spacing } \\
\end{array}$ & \\
\hline $6.91 \pm 0.51$ & $6.63 \pm 0.09$ & $8.81 \pm 0.44$ \\
\hline $5.67 \pm 0.72$ & $5.10 \pm 0.11$ & $6.96 \pm 0.64$ \\
\hline $4.17 \pm 1.15$ & $3.27 \pm 0.17$ & $6.23 \pm 0.22$ \\
\hline $2.36 \pm 0.18$ & $2.69 \pm 0.09$ & $3.18 \pm 0.54$ \\
\hline $1.42 \pm 0.15$ & $1.04 \pm 0.15$ & $1.07 \pm 0.19$ \\
\hline 0.0 & 0.0 & 0.0 \\
\hline
\end{tabular}

\footnotetext{
${ }^{a}$ The reflector is in contact with the tops and bottoms of the cylinders.

brror bars are about 70-percent confidence limits.

These calculations were performed by a staff member, Robert E. Rothe.

$\mathrm{d}_{\text {Top and bottom reflectors removed also. }}$
}

TABLE IX. Critical Center-to-Center Separation for an Infinite Line of Cylinders of Uranyl Fluoride $\left(\mathrm{UO}_{2} \mathrm{~F}_{2}\right)$ Solution Reflected by $\mathbf{3 0 . 4 8}$ Centimeters of Concrete(KENO II Calculations).

Cylinder Dia meter
(centimeters)

13.97

15.24

$1 \% \%$

Note: Cylinders are $250 \mathrm{ccntimeters}(\mathrm{cm})$ long and have $0.32-\mathrm{cm}$ thick stainless steel walls. Concrete is in contact with cylinder top and bottom and is $30.48 \mathrm{~cm}$ away from lateral surface.
${ }^{a}$ Critical Center-to-Center Spacing (centimeters)

$47.9 \pm 2.3$

$58,6 \pm 1.3$

117.910 .4

Errors are approximately 70-percent confidence limits.

TABLE X. Results of KENO Calculations on Ion-Column Arrays.

\begin{tabular}{|c|c|c|c|}
\hline Center Wall & ${ }^{a}$ Solution & Boron in Glass & $k_{\text {eff }} \pm \sigma$ \\
\hline Present & Plutonium & Yes & $0.660 \pm 0.010$ \\
\hline${ }^{b}$ Absent & Plutonium & Yes & $0.645 \pm 0.009$ \\
\hline Present & Plutonium & ${ }^{c}$ No & $0.672 \pm 0.009$ \\
\hline Present & Uranium & Yes & $0.722 \pm 0.010$ \\
\hline
\end{tabular}

${ }^{a}$ The solution properties are given in Table 1 .

b The center wall might be destroyed in case of an accident.

c Since the boron content of the glass is not part of the design specification, it cannot be relied on to poison the system. 
Ion-Column Array:

A proposed ion-column array consists of a double line of cylinders separated by a water wall for biological shielding. Each line contains 6 ion columns, and the entire array is reflected below and on all 4 sides by a $5.1 \mathrm{~cm}$ thick cuboidal shell of water. The geometry of the array and the dimensions are shown in Figure 4. The ion columns normally contain plutonium nitrate solution at a concentration of less than 150 grams per liter $(\mathrm{g} / \mathrm{l})$. Calculated results are shown in Table X.

For the particular geometry chosen, the array is slightly more reactive with the $10.2-\mathrm{cm}$ thick center wall than without it, but the difference is not significant at the 95-percent confidence level. The boron content of the cylinder glass reduces the reactivity slightly, but again the difference is not statistically significant. Replacing the plutonium solution by uranium solution increases $k_{\text {eff }}$ by 9 percent. One can estimate from Table VIII that the critical diameter for $\mathrm{UO}_{2} \mathrm{~F}_{2}$ solution in this configuration is greater than $15.5 \mathrm{~cm}$.

\section{Solution Process Area:}

A proposed area for plutonium-solution processing consisted of a concrete room, $975 \mathrm{~cm}$ long and $305 \mathrm{~cm}$ wide. Included were a line of cylinders containing concentrated $(200 \mathrm{~g} / 1$ maximum) solution along one $975 \cdot \mathrm{cm}$ long wall and a line of cylinders containing dilute $(7 \mathrm{~g} / \mathrm{l}$ maximum) solution along the opposite wall. Details are noted in Figure 5. KENO II was used to calculate $\mathrm{k}_{\mathrm{eff}}$ for three cases. For the normal case, as described above, $\mathrm{k}_{\text {eff }}=$ $0.694 \pm 0.008$. For $200-\mathrm{g} / \mathrm{l}$ plutonium solution in both rows, $\mathrm{k}_{\text {eff }}=0.835 \pm 0.008$. Finally, for comparison, both rows of cylinders were filled with $\mathrm{UO}_{2} \mathrm{~F}_{2}$ solution (as described in Table I, Page 2), resulting in

$\mathrm{k}_{\text {eff }}=0.97,2 \pm 0.010$.

\section{REFERENCES}

1. Yardley Beers. Introduction to the Theory of Error. Addison-Wesley Publishing Company, Incorporated, Reading, Massachusetts. 1957.

FIGURE 4: Ion-Column Array.

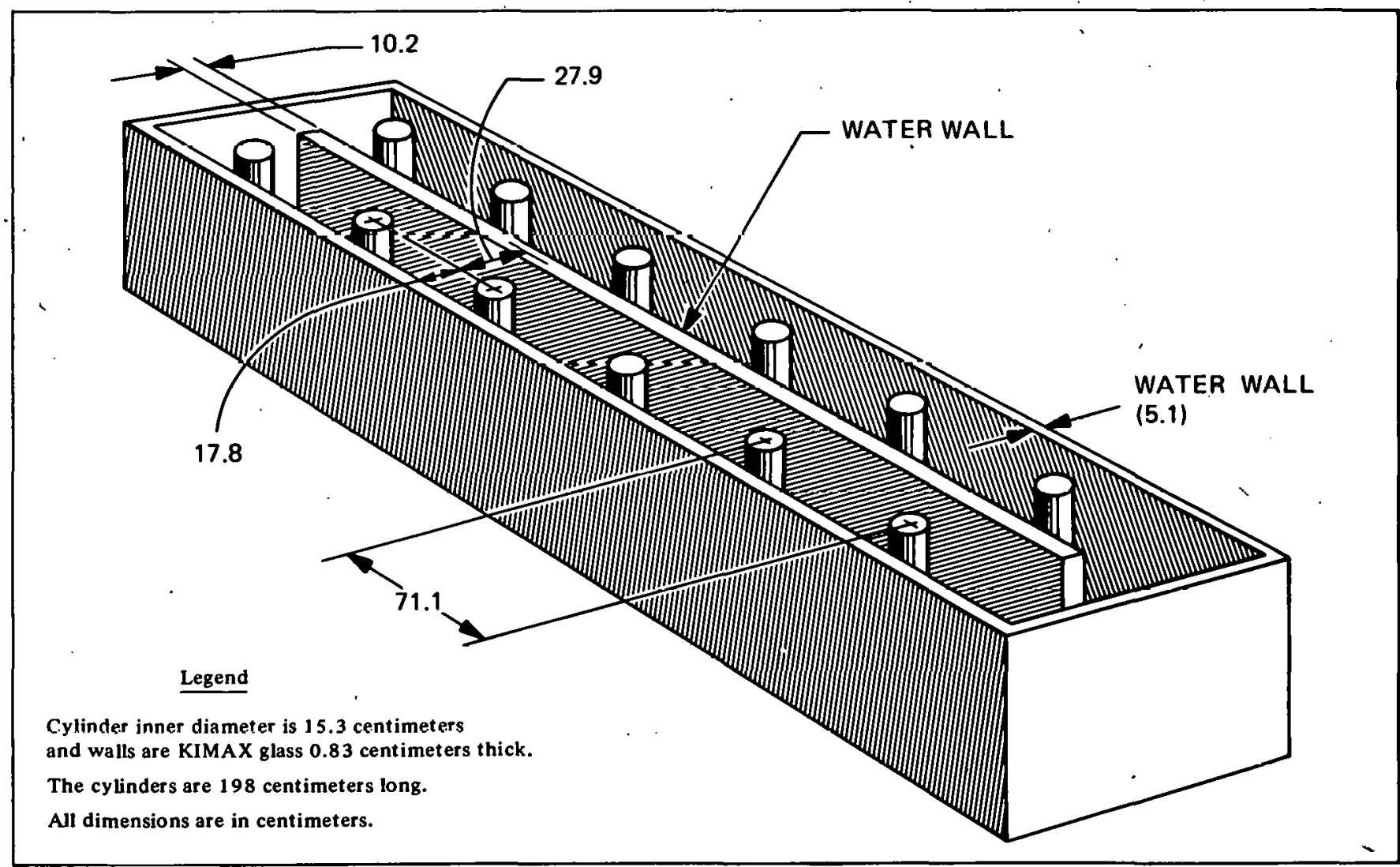




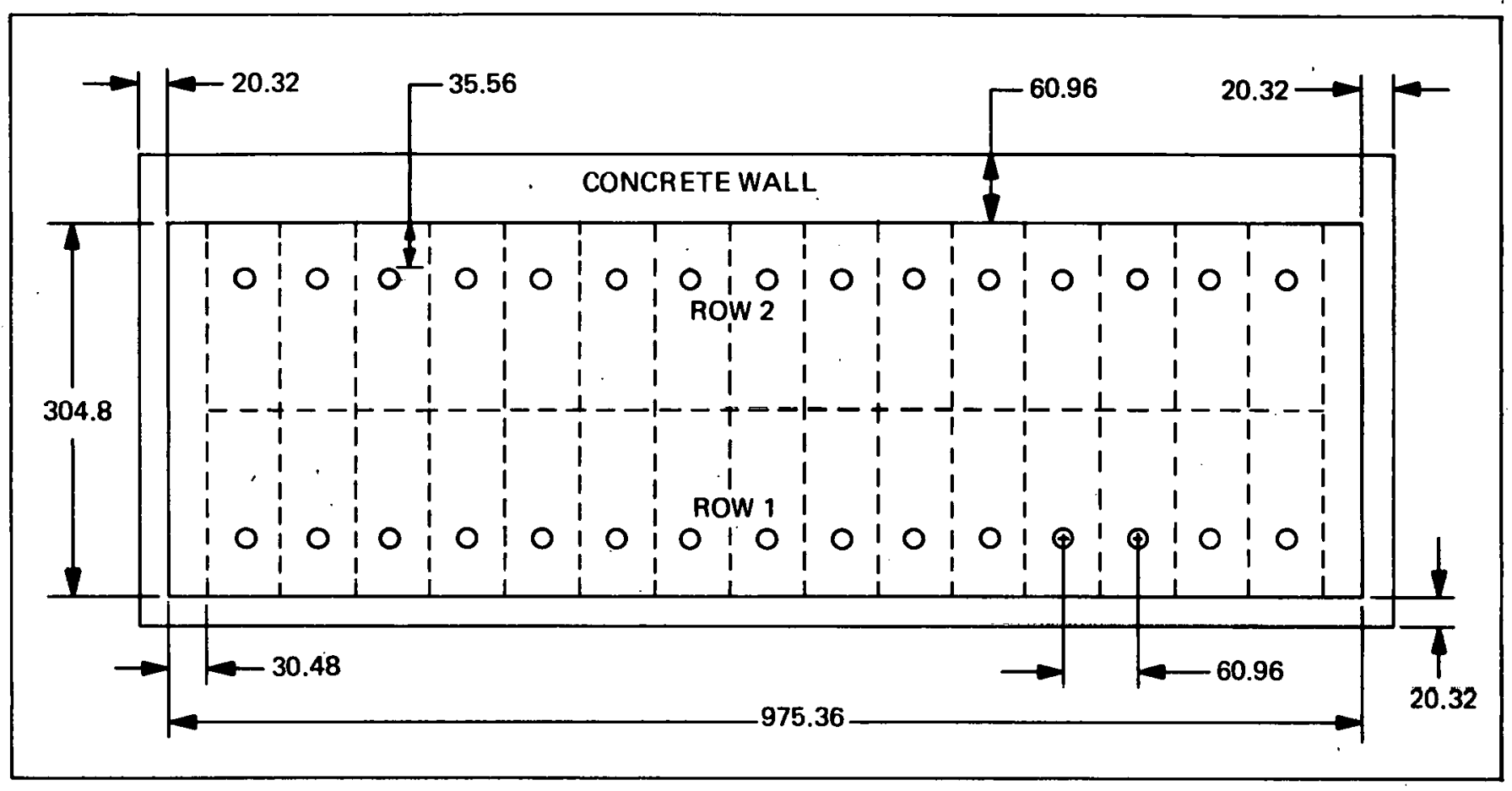

FIGURE 5. Double-Line Array of Cylinders. (All dimension in centimeters.) (Each cylinder has a $13.34-\mathrm{cm}$ inner diameter; $609.6-\mathrm{cm}$ inner height; and wall, top, and bottom of Type-304 stainless steel, $0.635-\mathrm{cm}$ thick. Floor and ceiling are $30.48-\mathrm{cm}$ thick concrete.

2. Jean-C'laude Bouly, Kobert C̀aizergues, Edouard Deilgat, Michel Houelle, and Louis Maubert. Interaction Neutronique dans l'Air de Récipients Cylindriques Contenant Soit des Solutions d'Uranium Soit des Solutions de Plutonium. CEA-R-3946. Service d'Etudes de Criticite. Paris, France. Mars 1970.

3. B. G. Carlson, W. J. Worlton, W. Guber, and M. Shapiro. DTF Users Manual. UNC PhysicsMathematics 3321. United Nuclear Corporation, White Plains, New York. Volume I, November 1963.

4. J. K. Fox. L. W. Gilley, and D. Callihan. Critical Mass Studies, Part IX, Aqueous $U^{235}$ Solutions (Continued). ORNL-2367. Oak Ridge National Laboratory, Oak Ridge, Tennessee. March 4, 1958.

5. Gordon E. Hansen and William H. Roach. Six and Sixteen Group Cross Sections for Fast and Intermediate Critical Assemblies. LAMS-2543. Los Alamos Scientific Laboratory, Los Alamos, New Mexico. December 1960.

6. J. F. Kenney and E. S. Keeping. Mathematics of Statistics, Part Two. D. VanNostrand Company, Incorporated, New York. 1951.
7. H. C. Paxton, J. T. Thomas, Dixon Callihan, and E. B. Johnson. Critical Dimensions of Systems Containing $U^{235}, \mathrm{Pu}^{239}$ and $U^{233}$ TID-7028. Oak Ridge National Laboratory, Oak Ridge, Tennessee; and Los Alamos Scientific Laboratory, Los Alamos, New Mexico. June 1964.

8. C. R. Richey. "Theoretical Analysis of Homogeneous Plutonium Critical Experiments." Nuclear Science and Engineering, $31: 32.1968$.

9. S. S. Shlapiru and M. B. Wilk. "An Analysis of Variance Test for Normality (Complete Samples)." Biomerrika, 52:591. 1965.

10. Grover Tuck and Harold E. Clark. "Critical Parameters of a Uranium Solution Slab-Cylinder System." Nuclear Science and Engineering, 40:407. 1970.

11. G. E. Whitesides and N. F. Cross. KENO; A Multigroup Monte Carlo Criticality Program. CTC-5. Nuclear Division, Computing Technology Center, Union Carbide Corporation, Oak Ridge, Tennessee. September 10, 1969.

12. G. E. Whitesides. Personal Communication. December 1971. 